\title{
A histopathological and biometric comparison between catfish (Pisces, Ariidae) from a harbor and a protected area, Brazil
}

\author{
Raimunda Nonata Fortes Carvalho Neta ${ }^{1 *}$, Débora Batista Pinheiro Sousa ${ }^{2}$, Zafira da Silva de Almeida ${ }^{1}$, \\ Débora Martins Silva Santos ${ }^{1}$ and Ligia Tchaicka ${ }^{1}$
}

\begin{abstract}
Background: Histopathological lesions and biometric variations in catfish species are statistically associated with chemical contaminant exposure. A histopathological and biometric database for the catfish Sciades herzbergii and Bagre bagre from São Luís Island (Port Area) and Caranguejos Island (Reference Area) is presented. Branchial and hepatic lesions were classified into three reaction patterns: 1) circulatory or inflammatory disturbances; 2) regressive changes; 3 ) progressive changes. This paper summarizes research efforts aimed at characterizing the biomonitoring potential of catfish from two islands in Brazil, which exhibit great habitat diversity and different levels of human intervention.
\end{abstract}

Results: The weights and lengths of the catfish caught at the Port Area were smaller than those from the Reference Area. No histopathological lesions were observed in S. herzbergii examined at the reference site (Caranguejos Island). In contrast, $90 \%$ of S. herzbergii from sites located in the Port Area (São Luís Island) had one or more types of branchial and hepatic lesions. One or more of the five lesions were observed on 16 B. bagre from São Luís Island and Caranguejos Island.

Conclusion: The utility of histopathological lesions and biometric data as sensitive indicators of the health of wild catfish populations has been demonstrated. Sciades herzbergii proved to be a better species for biomonitoring because it was more sensitive to the impacted site (Port Area) compared with the region relatively free of contaminants (Reference Area).

Keywords: Biomonitoring, Biomarkers, Sciades herzbergii, Bagre bagre

\section{Background}

Histopathological analysis in fish has already been tested and proposed as a sensitive tool for the monitoring of environmental contamination in natural water bodies [1]. Fish diseases, biometric data, and histopathology are increasingly being used as indicators of environmental stress because they provide a definite biological endpoint of historical exposure [2].

Biomarker analysis has been shown to be adequate for ascertaining the toxic effects of a given toxicant [3]. Biomarkers have been defined by measurable modifications

\footnotetext{
* Correspondence: raimundafortes@yahoo.com.br

'Department of Chemistry and Biology, State University of Maranhão (UEMA), São Luís, Maranhão, Brazil

Full list of author information is available at the end of the article
}

at the molecular, biochemical, cellular, physiological, and behavioral levels, revealing the exposure of a given organism to xenobiotics [4].

Gill lesions are used as sensitive biomarkers of environmental impacts on fish, and many researchers have recognized that histopathological examination is a valuable tool for assessment of environmental impacts on fish populations [5] because morphologic alterations can occur as gills are in permanent contact with the environment [6]. The detection of early warning signals through branchial and hepatic lesions in fish is ecologically relevant, economically beneficial, more efficient, and has the potential to be used as a type of biomarker [7].

In São Luís Island (São Marcos Bay, Maranhão), the catfish Sciades herzbergii, a benthic fish common to

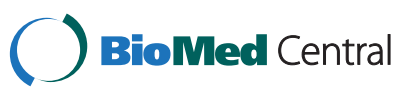

(c) 2014 Carvalho Neta et al.; licensee BioMed Central Ltd. This is an Open Access article distributed under the terms of the Creative Commons Attribution License (http://creativecommons.org/licenses/by/4.0), which permits unrestricted use, distribution, and reproduction in any medium, provided the original work is properly credited. The Creative Commons Public Domain Dedication waiver (http://creativecommons.org/publicdomain/zero/1.0/) applies to the data made available in this article, unless otherwise stated. 
Brazil coastal areas, has been identified as a model species for investigating the effects of contamination in estuarine systems [3]. Bagre bagre, another catfish, resides in both contaminated and clean estuarine environments around the São Marcos Bay. This species is particularly suitable for this research because of its commercial importance and sedentary lifestyle.

São Marcos Bay is an important fishing location and has the most important harbor in northeastern Brazil. However, in the last decade, chemical contamination from industrial waste has posed an increasing threat to the health of aquatic organisms $[7,8]$. In contrast, Caranguejos Island constitutes a wildlife reserve in São Marcos Bay that covers a large mangrove area [8]. The increasing emphasis in Brazil on monitoring estuarine and marine ecosystems has highlighted the need to deploy appropriate biological measurements for these locations [8]. This study gathers and compares biometric data and histopathological lesions of $S$. herzbergii and B. bagre from ecologically diverse ecosystems on two distinct Islands in São Marcos Bay, Brazil.

\section{Results and discussion}

Environmental parameters

The water from the two sites (São Luís and Caranguejos Islands) exhibited distinct characteristics and contamination profiles (Table 1 ). The concentrations of $\mathrm{Al}, \mathrm{Cd}, \mathrm{Pb}$, $\mathrm{Cr}$, Fe, and $\mathrm{Hg}$, in São Luís Island were higher than the acceptable limit by national Brazilian standards (CONAMA, Conselho Nacional do Meio Ambiente). The average water surface temperatures were constant during both periods analyzed. Salinity was uniform in both areas sampled, being lower during the rainy season in both areas. Dissolved oxygen and the saturation of dissolved oxygen were always lower in the contaminated area. The values for $\mathrm{pH}$ were constants for both areas. The habitats of each of the different sites were identical in aquatic plants, substrate, and fauna.
Abiotic factors such as water temperature, conductivity, $\mathrm{pH}$, and dissolved oxygen can change the fish richness and assemblage composition [8-10], which can also be affected by anthropogenic impacts [11]. The similar $\mathrm{pH}$ values recorded for the two analyzed areas indicate a dynamic region where the winds, tides, and river discharges determine a high load of particulate matter. All heavy metals concentrations ( $\mathrm{Al}, \mathrm{Cd}, \mathrm{Pb}, \mathrm{Cr}, \mathrm{Fe}, \mathrm{Hg}$ ) in water collected from the potentially contaminated area were significantly higher than water from the reference area. Previous studies on sediment and water in the harbor area showed significantly higher levels of mercury and chrome, which confirms that the port area in São Marcos Bay is a site with high exposure risks for some contaminants $[3,7,8]$. Öztürk et al. [12] have determined the level of heavy metals in various tissues of the Cyprinus carpio species and they reported that cadmium, chromium, nickel, and lead concentrations exceeded the tolerable values provided by international institutions. These authors have reported that heavy metal concentrations in gill samples can decrease in the sequence: $\mathrm{Fe}(0.15 \mathrm{mg} / \mathrm{kg})>\mathrm{Cu}$ $(3.94 \mathrm{mg} / \mathrm{kg})>\mathrm{Pb} \quad(3.11 \mathrm{mg} / \mathrm{kg})>\mathrm{Cr} \quad(1.61 \mathrm{mg} / \mathrm{kg})>\mathrm{Cd}$ $(0.15 \mathrm{mg} / \mathrm{kg})$, and for the liver as Fe $(94.27 \mathrm{mg} / \mathrm{kg})>\mathrm{Cu}$ $(9.73 \mathrm{mg} / \mathrm{kg})>\mathrm{Pb}(3.42 \mathrm{mg} / \mathrm{kg})>\mathrm{Cr} \quad(0.83 \mathrm{mg} / \mathrm{kg})>\mathrm{Cd}$ (0.79 mg/kg).

\section{Biometric data}

Biometric parameters (total length - Lt, furcal length - Lf, total weight - Wt and gonad weight - Wg) of collected fish are showed in Tables 2 and 3. As expected, most populations of catfish considered in this study are highly heterogeneous, with lengths and weights deviating from the reference sample. At the reference site (A1), catfish were bigger $(\mathrm{P}<0.05)$ than those from the harbor area (A2). Fish across all gonadal stages were found in the reference area, but juveniles (GS1) were not found in the potentially contaminated site. The gonadosomatic index

Table 1 Physical and chemical analysis of water at two sites in São Marcos Bay (Brazil)

\begin{tabular}{|c|c|c|c|c|}
\hline \multirow[t]{2}{*}{ Parameters } & \multicolumn{2}{|c|}{ Reference (A1) } & \multicolumn{2}{|c|}{ Contaminated (A2) } \\
\hline & Dry period* & Rainy period ${ }^{y}$ & Dry period* & Rainy period ${ }^{y}$ \\
\hline Temperature $\left({ }^{\circ} \mathrm{C}\right)$ & 30.5 & 29.5 & 30.5 & 29.5 \\
\hline Salinity (UPS) & 15 & 14 & 19 & 18 \\
\hline $\mathrm{pH}$ & 7.98 & 7.99 & 7.94 & 7.94 \\
\hline $\mathrm{OD}\left(\mathrm{mg} / \mathrm{L} \mathrm{O}_{2}\right)$ & 6.0 & 6.1 & 4.9 & 5.1 \\
\hline Aluminum (mg/L) & 0.02 & 0.02 & 0.1 & 0.1 \\
\hline Cadmium (mg/L) & 0.001 & 0.001 & 0.007 & 0.006 \\
\hline Lead (mg/L) & 0.001 & 0.000 & 0.02 & 0.02 \\
\hline Chromium (mg/L) & 0.08 & 0.07 & 0.02 & 0.1 \\
\hline Iron (mg/L) & 0.01 & 0.01 & 0.07 & 0.07 \\
\hline Mercury (mg/L) & 0.000 & 0.000 & 0.001 & 0.001 \\
\hline
\end{tabular}

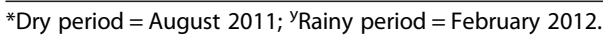


Table 2 Biometric data and gonadosomatic index of S. herzbergii caught in São Marcos Bay, Maranhão, Brazil

\begin{tabular}{lllllll}
\hline Sites & Gender & $\mathbf{L}_{\mathbf{t}}(\mathbf{c m})$ & $\mathbf{L}_{\mathbf{f}}(\mathbf{c m})$ & $\mathbf{W}_{\mathbf{t}} \mathbf{( g )}$ & $\mathbf{W}_{\mathbf{g}} \mathbf{( g )}$ & $\mathbf{G S I}$ \\
\hline Reference (A1) & Female & $29.85 \pm 2.72^{*}$ & $26.29 \pm 2.98^{*}$ & $283.45 \pm 57.34^{*}$ & $7.936 \pm 0.361$ & $2.68 \pm 0.26^{*}$ \\
& Male & $28.85 \pm 2.81^{*}$ & $27.29 \pm 2.21^{*}$ & $281.25 \pm 37.54^{*}$ & $5.434 \pm 0.251$ & $1.58 \pm 0.12^{*}$ \\
Harbor (A2) & Female & $20.88 \pm 3.22$ & $19.45 \pm 2.74$ & $108.50 \pm 77.90$ & $0.629 \pm 0.447$ & $0.08 \pm 0.063$ \\
& Male & $18.28 \pm 8.72$ & $16.25 \pm 2.92$ & $105.31 \pm 55.60$ & $0.129 \pm 0.047$ & $0.02 \pm 0.013$ \\
\hline
\end{tabular}

*Indicates significant difference between sites $(P<0.05)$. Total number of catfish $=60$. Number of female catfish in: $A 1=15 ; A 2=15$. Number of male catfish in: $A 1=15 ; A 2=15$. Biometric data: $L_{t}$ (total length); $L_{f}$ (fork length); Wg (gonad weight), and GSI (gonadosomatic index). $\mathrm{cm}$ (centimeter); $g$ (gram).

(GSI) was also higher in the reference site than in the contaminated site during both periods $(\mathrm{P}<0.05)$. In a similar study, the GSI in S. herzbergii from the potentially contaminated site (São Marcos Bay) was significantly lower than in control fish during all the phases of the gonadal cycle [3-5]. Carvalho-Neta et al. [3] have shown a decrease in the GSI of catfishes from harbor areas in Brazil, and have suggested this decrease can result in abnormal gonadal development in the form of delayed maturation, high levels of atresia, or intersexuality in fish.

\section{Branchial and hepatic lesions}

No deformation of the gills and livers were observed in $\mathrm{S}$. herzbergii collected in the reference area. However, more than half (90\%) of catfish (S. herzbergii) collected in the contaminated area showed moderate to severe gill and liver damage (Table 4). No ectoparasites or endoparasites were observed in $S$. herzbergii, which suggests that other environmental parameters may have been the cause of observed gill lesions. As opposed to what was observed in S. herzbergii, more than $86.33 \%$ of B. bagre individuals showed histopathological alterations in both areas (Table 4). Several ectoparasites were observed in $B$. bagre. The migratory behavior and parasitosis observed in $B$. bagre seems to explain the number of lesions observed in individuals from both areas [13-19]. However, S. herzbergii is a resident and non-migratory estuarine species of catfish $[16,17]$.

The histopathological examination performed in the gill epithelium of catfish $S$. herzbergii could clearly differentiate the region of Caranguejos Island (reference - A1) and the harbor site (contaminated - A2). Sciades herzbergii is a benthic and resident species of catfish. The great number of moderate and severe branchial and hepatic lesions indicates that harbor fish are stressed by the pollutants. Branchial and hepatic lesions such as the profusion and dilation of blood vessels, presence of melanomacrophages, and epithelial lifting are examples of defense mechanisms [13,14].

In São Marcos Bay, the integrated analysis of morphological lesions and biometric data were useful because histopathological alterations were detected only in catfish of the Port area [7]. Furthermore, in that area, GSI was very low and juvenile fish were not found. Carvalho-Neta et al. [8] observed the same situation at São Marcos Bay and they suggested a method of correlating branchial and hepatic lesions with biometric data for biomonitoring in this region.

As the data on S. herzbergii lesions were more consistent for differentiating the two regions of São Marcos Bay, we made correlations between these morphological changes. Cluster analyses derived correlations between lesions (Figures 1 and 2). Regarding hepatic lesions, three groups of lesions were conspicuous. The first group comprises profusion and dilation of blood vessels (L1), presence of melanomacrophages (L2) and lipidosis (L5); the second group comprises nuclear pleomorphisms (L3) and necrosis (L4); and the third group comprises eosinophilic hepatocellular alteration (L6) and granulomatous lesions (L7). These clusters indicate prolonged physiological disturbances that led to glycogen depletion and lipid storage. These lesions, like melanomacrophages associated with lipidosis (intracellular lipid storage in large vacuoles) have been observed in wild fish from sites contaminated by mixtures of xenobiotics $[20,21]$.

In gills, the strongest correlation was observed between deformation of lamellae (L12) and lamellar fusion (L15). The second group comprises epithelial hyperplasia

Table 3 Biometric data and gonadosomatic index of B. bagre caught in São Marcos Bay, Maranhão, Brazil

\begin{tabular}{lllllll}
\hline Sites & Gender & $\mathbf{L}_{\mathbf{t}}(\mathbf{c m})$ & $\mathbf{L}_{\mathbf{f}}(\mathbf{c m})$ & $\mathbf{W}_{\mathbf{t}} \mathbf{( g )}$ & $\mathbf{W}_{\mathbf{g}} \mathbf{( g )}$ & $\mathbf{G S I}$ \\
\hline Reference (A1) & Female & $26.32 \pm 1.82^{*}$ & $24.29 \pm 2.01^{*}$ & $222.65 \pm 14.34^{*}$ & $5.895 \pm 0.351$ & $1.51 \pm 0.85^{*}$ \\
& Male & $27.21 \pm 1.31^{*}$ & $25.29 \pm 1.21^{*}$ & $228.15 \pm 13.54^{*}$ & $1.434 \pm 0.451$ & $0.58 \pm 0.11^{*}$ \\
Harbor (A2) & Female & $20.53 \pm 4.44$ & $18.45 \pm 2.74$ & $104.50 \pm 57.90$ & $0.729 \pm 0.57$ & $0.08 \pm 0.02$ \\
& Male & $18.28 \pm 8.72$ & $16.05 \pm 3.92$ & $102.11 \pm 35.60$ & $0.129 \pm 0.08$ & $0.03 \pm 0.01$ \\
\hline
\end{tabular}

*Indicates significant difference between sites $(P<0.05)$. Total number of catfish $=60$. Number of female catfish in: $A 1=15 ; A 2=15$. Number of male catfish in: $A 1=15 ; A 2=15$. Biometric data: $L_{t}$ (total length); $L_{f}$ (fork lengt); $\mathrm{Wg}$ (gonad weight), and GSI (gonadosomatic index). cm (centimeter); $g$ (grama). 
Table 4 Observed pathologies and their importance factor (w) and percentages (\%) in catfish from São Marcos Bay

\begin{tabular}{|c|c|c|c|c|c|}
\hline Target organ & Reaction pattern & Alteration* $^{*}$ & w & \% S. herzbergii & $\%$ B. bagre \\
\hline \multirow[t]{8}{*}{ Liver } & \multirow[t]{2}{*}{ Inflammatory response } & Profusion and dilation of blood vessels (L 1 ) & 1 & $\mathrm{~A} 1=0 / \mathrm{A} 2=93.33$ & $\mathrm{~A} 1=43.33 / \mathrm{A} 2=66.66$ \\
\hline & & Presence of melanomacrophages (L2) & 1 & $\mathrm{~A} 1=0 / \mathrm{A} 2=93.33$ & $\mathrm{~A} 1=32.33 / \mathrm{A} 2=66.66$ \\
\hline & \multirow[t]{2}{*}{ Regressive changes } & Nuclear pleomorphisms (L3) & 2 & $\mathrm{~A} 1=0 / \mathrm{A} 2=66.66$ & $\mathrm{~A} 1=23.33 / \mathrm{A} 2=66.66$ \\
\hline & & Necrosis (L4) & 3 & $\mathrm{~A} 1=0 / \mathrm{A} 2=90.00$ & $\mathrm{~A} 1=16.66 / \mathrm{A} 2=86.66$ \\
\hline & \multirow[t]{4}{*}{ Progressive changes } & Lipidosis (L5) & 1 & $\mathrm{~A} 1=0 / \mathrm{A} 2=66.66$ & $A 1=16.66 / A 2=86.66$ \\
\hline & & Eosinophilic hepatocellular alteration (L6) & 2 & $\mathrm{~A} 1=0 / \mathrm{A} 2=86.66$ & $\mathrm{~A} 1=16.66 / \mathrm{A} 2=66.66$ \\
\hline & & Granulomatous lesions (L7) & 2 & $\mathrm{~A} 1=0 / \mathrm{A} 2=86.66$ & $\mathrm{~A} 1=43.33 / \mathrm{A} 2=90.00$ \\
\hline & & Presence of eosinophilic bodies (L8) & 2 & $\mathrm{~A} 1=0 / \mathrm{A} 2=90.00$ & $A 1=66.66 / A 2=86.66$ \\
\hline \multirow[t]{8}{*}{ Gills } & Circulatory disturbances & Lamellar capillary aneurism (L9) & 1 & $\mathrm{~A} 1=0 / \mathrm{A} 2=63.33$ & $A 1=16.66 / A 2=96.66$ \\
\hline & \multirow[t]{4}{*}{ Regressive changes } & Epithelial lifting (L10) & 1 & $A 1=0 / A 2=63.33$ & $A 1=90.00 / A 2=86.66$ \\
\hline & & Epithelial desquamation (L11) & 1 & $\mathrm{~A} 1=0 / \mathrm{A} 2=23.33$ & $\mathrm{~A} 1=23.33 / \mathrm{A} 2=43.33$ \\
\hline & & Deformation of lamellae (L12) & 1 & $\mathrm{~A} 1=0 / \mathrm{A} 2=90.00$ & $A 1=16.66 / A 2=66.66$ \\
\hline & & Mucous (goblet) cell degeneration (L13) & 2 & $\mathrm{~A} 1=0 / \mathrm{A} 2=90.00$ & $\mathrm{~A} 1=33.33 / \mathrm{A} 2=86.00$ \\
\hline & \multirow[t]{3}{*}{ Progressive changes } & Hypertrophy of squamous epithelia (L14) & 1 & $\mathrm{~A} 1=0 / \mathrm{A} 2=23.33$ & $\mathrm{~A} 1=23.33 / \mathrm{A} 2=16.66$ \\
\hline & & Lamellar fusion (L15) & 1 & $\mathrm{~A} 1=0 / \mathrm{A} 2=93.33$ & $\mathrm{~A} 1=43.33 / \mathrm{A} 2=93.33$ \\
\hline & & Epithelial hyperplasia (L16) & 2 & $\mathrm{~A} 1=0 / \mathrm{A} 2=93.33$ & $\mathrm{~A} 1=16.66 / \mathrm{A} 2=86.33$ \\
\hline
\end{tabular}

A1 = reference; $\mathrm{A} 2$ = contaminated area.

*Only persistent pathologies within an organ were scored as observed. Alterations that did not qualify as representative of the overall organ condition were disregarded, being considered as natural variations.

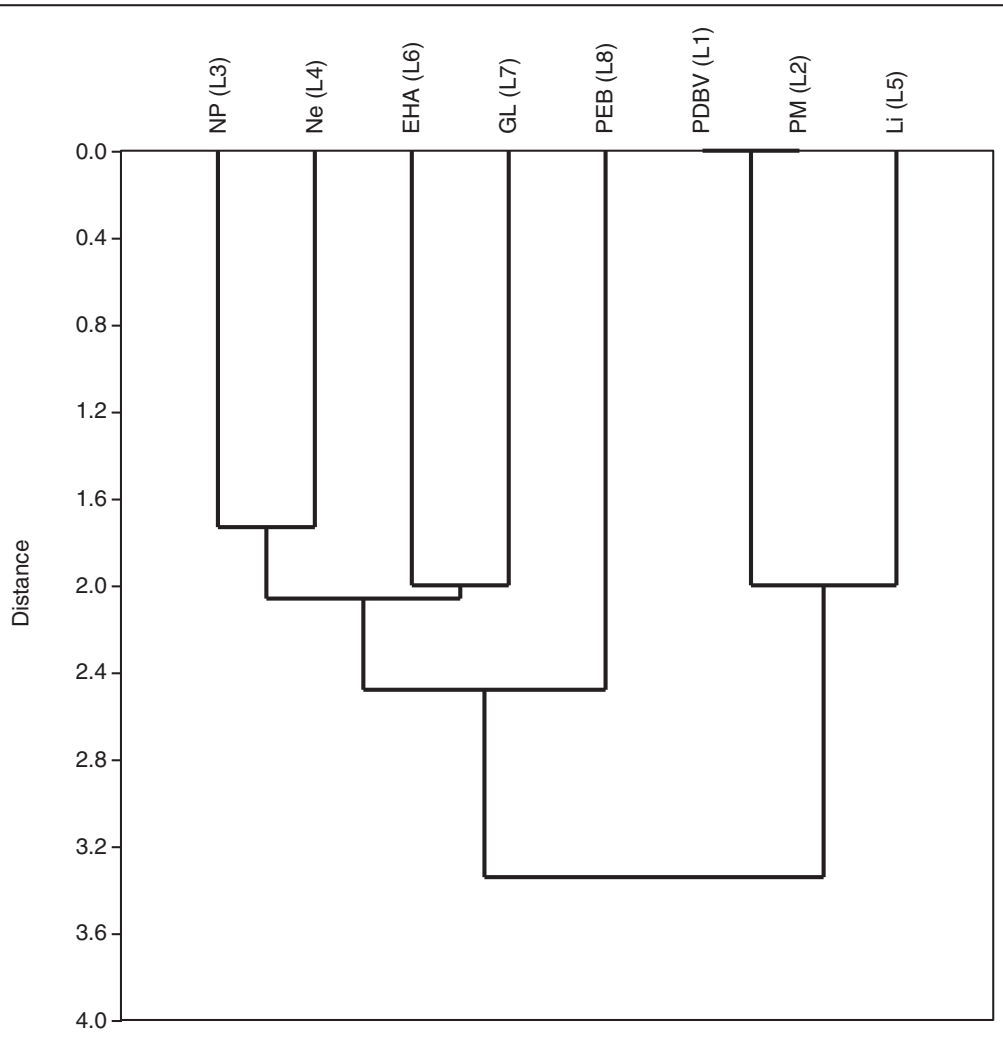

Figure 1 Joining tree of observed lesions in the liver of Sciades herzbergii from a port area in São Marcos Bay, Brazil. Distances were obtained from presence and absence data and estimated as 1-Pearson r. Joining is based on unweighted pair-group averages. 


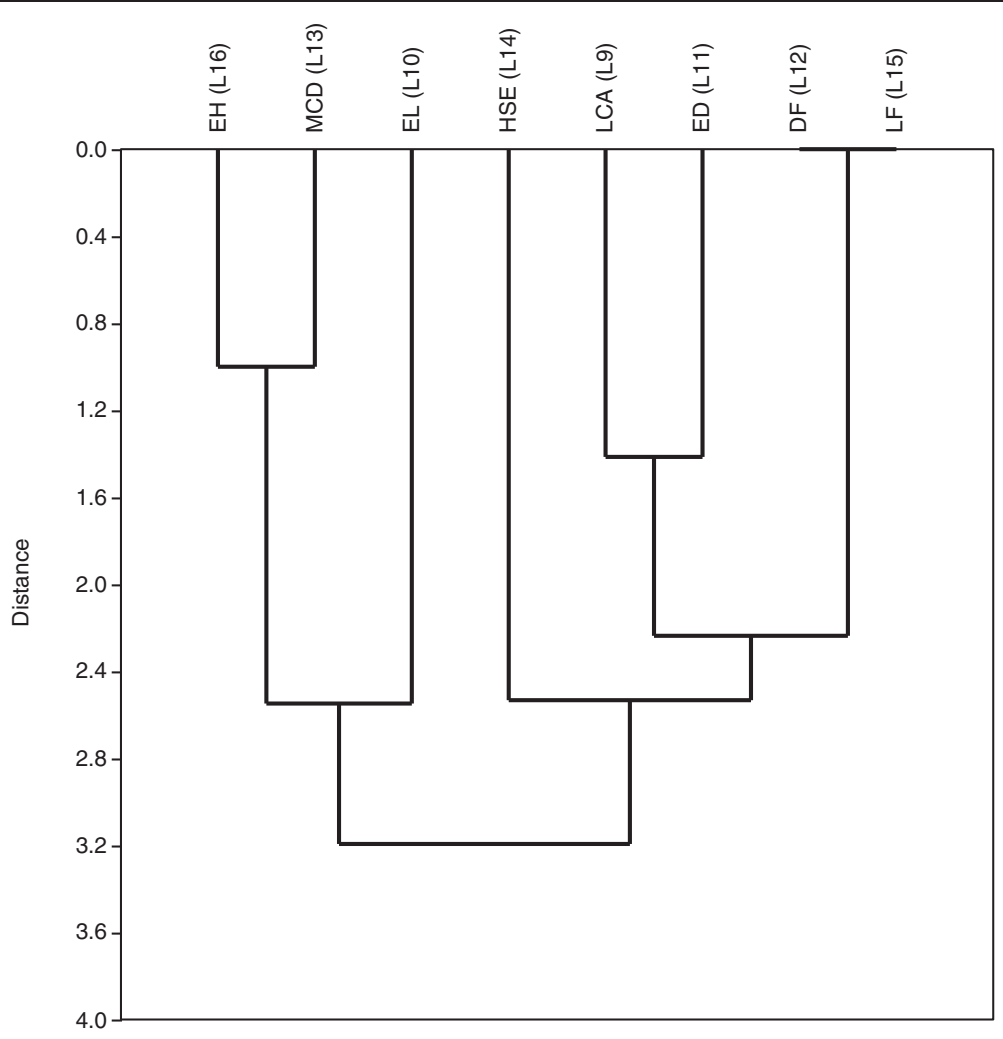

Figure 2 Joining tree of observed lesions in the gills of Sciades herzbergii from a port area in São Marcos Bay, Brazil. Distances were obtained from presence and absence data and estimated as 1-Pearson r. Joining is based on unweighted pair-group averages.

(L16) and mucous cell degeneration (L13). The third group was formed by lamellar capillary aneurism (L9) and epithelial desquamation (L11). A similar joining tree was observed in the gills of juvenile Solea senegalensis exposed to contaminated estuarine sediments, indicating exposure to heavy metals [22]. This result suggests that gills are more susceptible to the acute effects of exposure to contaminants and livers are subjected to the chronic effects of xenobiotics.

\section{Conclusion}

The present study demonstrates that S. herzbergii has great suitability for monitoring estuarine areas, especially on the basis of branchial lesions (acute effects), because the species shows greater sensitivity to an impacted area (harbor) compared with one relatively free of contaminants (reference).

\section{Methods}

\section{Study areas}

We studied two sites along São Marcos Bay (Figure 3), Maranhão, Brazil. The first site (A1) is located in Crab Island (02 $49^{\prime} 06^{\prime \prime} \mathrm{S}$ and $\left.044^{\circ} 29^{\prime} 05^{\prime \prime} \mathrm{W}\right)$ and was used a reference site because it is a natural reserve. The second site (A2) is located in the Port of Itaqui $\left(02^{\circ} 43^{\prime} 14^{\prime \prime} \mathrm{S}\right.$ and $\left.044^{\circ} 23^{\prime} 35^{\prime \prime} \mathrm{W}\right)$, and was used to represent an impacted area because it receives agricultural, industrial, and domestic sewage effluents as well as harbor-related residuals [3].

The Port of Itaqui is located to the west coast of São Luis Island. The infrastructure of this port comprises a 1,616 m extension of quaysides. Fuel, iron, ore, manganese, grains, fertilizers, petroleum, bauxite, and alumina are shipped in this port [23].

The Caranguejos Island, situated at a distance of $30 \mathrm{~km}$ from the Itaqui port in São Marcos Bay, is an environment-protected area created by the government of the Maranhão. This region is uninhabited and occupies an area of $345.08 \mathrm{~km}^{2}$, containing the largest continuous stretch of mangrove in Maranhão [16].

\section{Sample collection}

Specimens of S. herzbergii (common name in English is pemecou sea catfish and in Portuguese is bagre guribu) and $B$. bagre (common name in English is coco sea catfish and in Portuguese is bagre-bandeirado) were collected from three streams, about a kilometer from each other at each site (A1 and A2). Fish were captured during the rainy period (August 2011) and the dry period (February 2012). The capture of fish was authorized by 


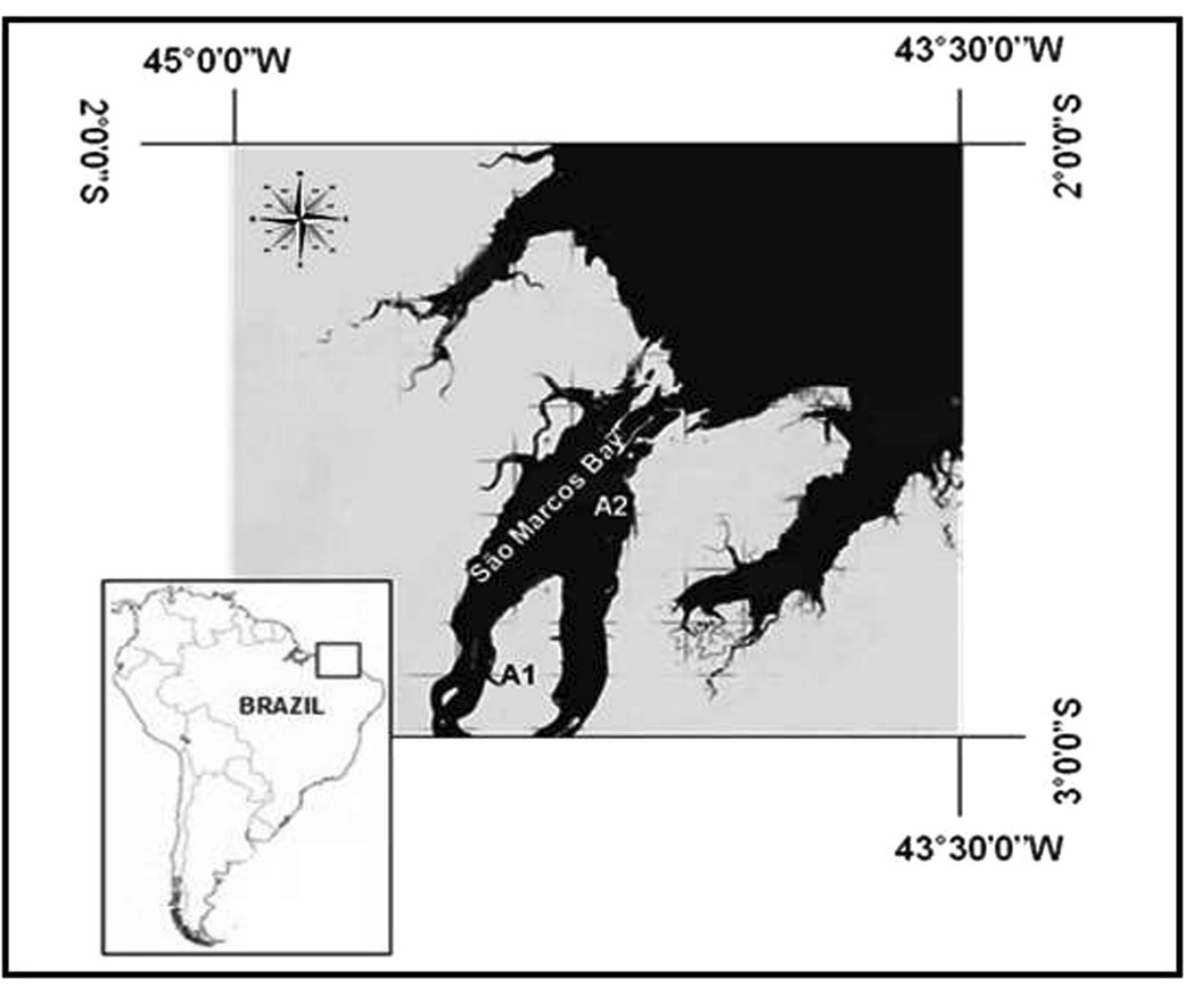

Figure 3 São Marcos Bay, Maranhão Brazil. A1 = Crab Island. A2 = São Luís Island.

the local environmental agency (Secretaria de Estado de Meio Ambiente e Recursos Naturais - SEMA), number $001 / 12$. Thirty fish in the potentially impacted area and 30 fish in the reference area were randomly sampled. The sexes for these fish by season were: A1) eight male and seven female fish in the dry season; seven male and eight female fish in the wet season; A2) nine male and six female fish in the dry season; eight male and seven female fish in the wet season. Fish were killed by transspinal dissection and immediately transported in an isothermal box (equipped with refrigeration system) to the laboratory.

Water samples were collected from the port area and the reference area for determination of contaminant levels. The concentrations of metals in water were determined using flame atomic absorption spectrophotometry (AAS), with a nitrous oxide-acetylene flame [24].

\section{Biometric data and somatic index}

The total length (Lt), standard length (Ls), furcal length (Lf), total weight (Wt), and gonad weight (Wg) of each fish were recorded. The macroscopic classification of the gonadal stage (GS) was also undertaken: GS1 (immature), GS2 (maturing or at rest), GS3 (mature), and GS4 (spent), following the scale given by Carvalho-Neta and Castro [16]. The gonadosomatic index (GSI) was calculated in accordance with Vazzoler [25].

\section{Histopathological analysis}

Fish were dissected and their gills and livers were fixed immediately in $10 \%$ formalin. The gills and livers of each individual were dehydrated in a progressive series of ethanol dilutions and embedded in paraffin. Sections were stained with hematoxylin and counterstained with alcoholic eosin for structural analysis of gills and liver. Four tissue sections from each fish were examined by Zeiss light photomicroscope. Histopathological lesions were classified according to Bernet et al. [1] into three reaction patterns: 1) circulatory disturbances; 2) regressive changes; 3) progressive changes. We considered 16 types of histopathological lesions. Every alteration has an importance factor (w) from 1 to 3 where $1=$ minimal pathological importance (the lesion is easily reversible); 2 = moderate pathological importance (the lesion is reversible in most cases); 3 = marked pathological importance (the lesion is generally irreversible) [1].

\section{Statistical analysis}

Results were expressed as mean \pm standard deviation. T-tests and one-way analysis of variance were used to test for significant differences between groups (on the contaminated and the reference site) and only $\mathrm{p}<0.05$ was accepted as significant. Biometric data (LT, LS, LF, WT, WG, and GSI) were calculated using the mean values observed for each parameter. Cluster analysis was 
based on correlation matrices by computing Pearson's $r$ statistic. Pairwise correlations were obtained through the Spearman's rank-order correlation "p". The significance level was set at $\mathrm{p}=0.05$.

\section{Abbreviations}

GSI: Gonadossomatic Index; Lt: Total length; Lf: Fork length; Wg: Gonad weight; cm: Centimeter; g: Gram.

\section{Competing interests}

The authors declare that they have no competing interests.

\section{Authors' contributions}

RNFCN designed the manuscript, performed data analyses, and drafted the manuscript. DBPS co-designed the manuscript and carried out the histopathological studies and drafted the manuscript. ZSA, LT and DMSS co-designed the manuscript and helped draft the manuscript. All authors read and approved the final manuscript.

\section{Authors' information}

DBPS is a biologist and an expert in histological and genotoxic biomarkers. ZSA has a PhD and is an expert in fisheries.

DMSS has a PhD and is an expert in fish histopathology.

LT has a PhD and is an expert in Genetics.

RNFCN has a PhD and is an expert in histological and biochemical biomarkers in fish.

\section{Acknowledgments}

We would like to acknowledge the "Laboratory of Fishing and Aquatic Ecology" for the facilitation of sampling in the study area, and Technological Development - FAPEMA (Fundação de Amparo à Pesquisa e ao Desenvolvimento Científico e Tecnológico do Estado do Maranhão), for financial support. We are grateful to HC, DMSS, and ALAS for technical support.

\section{Author details}

'Department of Chemistry and Biology, State University of Maranhão (UEMA), São Luís, Maranhão, Brazil. ${ }^{2}$ Postgraduate Program of Aquatic Resources and Fishery (PPGRAP/UEMA), State University of Maranhão, São Luís, Maranhão, Brazil.

Received: 25 May 2014 Accepted: 21 November 2014

Published online: 14 December 2014

\section{References}

1. Bernet D, Schmidt H, Meier W, Burkhardt-Holm P, Wahli T: Histopathology in fish: proposal for a protocol to assess. Journ Fish Disea 1999, 22:25-34.

2. Stentiford GD, Longshaw M, Lyons BPJ, Green GM, Feist SW: Histopathological biomarkers in estuarine fish species assessment of biological effects of contaminats. Mar Environ Res 2003, 55:137-159.

3. Carvalho-Neta RNF, Abreu-Silva AL: Sciades herzbergii oxidative stress biomarkers: an in situ study of estuarine ecosystem (São Marcos' Bay, maranhão, brazil). Braz Jour Oceanogr 2010, 58:11-17.

4. Depledge MH, Aagaard A, Gyorkos R: Assessment of trace metal toxicity using molecular, physiological and behavioural biomarkers. Mar Pollut Bul 1995, 31:19-27.

5. The SJ, Adams SM, Hinton DE: Histopathologic biomarkers in feral freshwater fish populations exposed to different types of contaminant stress. Aquat Toxicol 1997, 37:51-70

6. Heath AG: Water Pollution and Fish Physiology. Virginia: Lewis Publishers; 1995. $359 \mathrm{pp}$

7. Sousa DBP, Almeida ZS, Carvalho-Neta RNF: Biomarcadores em duas espécies de bagres estuarinos da costa maranhense. Arg Bras Med Vet Zootec 2013, 65:369-376.

8. Carvalho-Neta RNF, Torres AR Jr, Abreu-Silva AL: Biomarkers in catfish sciades herzbergii (teleostei: ariidae) from polluted and Non-polluted areas (São Marcos' Bay, northeastern brazil). Appl Biochem Biotec 2012, 166:1-12.

9. Fialho AP, Oliveira LG, Tejerina-Garro FL, Mérona B: Fish-habitat relationship in a tropical river under anthropogenic influences. Hydrob 2008, 598:315-324.
10. Pinheiro-Sousa DB, Almeida ZS, Carvalho-Neta RNF: Integrated analysis of two biomarkers in Sciades herzbergii (Ariidae, Siluriformes) to assess the environmental impact at São Marcos' Bay, Maranhão. Brazil Lat Am J Aquat Res 2013, 41:305-312.

11. Penczac T, Agostinho AA, Okada EK: Fish diversity and community structure in two tributaries of the Paraná River, Paraná State, Brazil. Hydrob 1994, 294:243-251.

12. Oztürk M, Ozözen G, Minareci O, Minareci E: Determination of heavy metals in fish, water and sediments of Avsar Dam Lake in Turkey. Iran J Environ Health 2009, 6(2):73-80.

13. Camargo MMP, Martinez CBR: Histopathologic of gills, Kidney and liver of a Neotropical fish caged in an urban stream. Neotrop Ichthyol 2007, 5:327-336.

14. Fernandes MN, Mazon AF: Environmental Pollution and Fish Gill Morphology. In Fish Adaptations. Edited by Val L, Kapoor BG. Cambridge: Enfield Science Publishers; 2003:203-231.

15. Lee J-W, Kim J-W, Riu D, Moniello G, Hung SSO: Histopathological alterations of juvenile green (Acipenser medirostris) and white sturgeon (Acipenser transmontanus) exposed to graded levels of dietary methylmercury. Aqua Toxic 2012, 109:90-99.

16. Carvalho-Neta RNF, Castro ACL: Diversidade das assembléias de peixes estuarinos na llha dos Caranguejos, Maranhão. Arq Cien Mar 2008, 41:48-57.

17. Carvalho-Neta RNF, Nunes JLS, Piorsk NM: Peixes Estuarinos do Maranhão. In Peixes Marinhos e Estuarinos do Maranhão. Edited by Nunes JLS, Piorski NM. São Luís/ Brazil: São Luís: Café \& Lápis - FAPEMA; 2011:95-104.

18. Absolon BA, Andreata JV: Variação espacial dos bagres (Siluriformes, Ariidae) coletados na Baía da Ribeira, Angra dos Reis, Rio de Janeiro, e prováveis influências da temperatura e salinidade. Rer Agron Mei Ambiem 2009, 2:155-165.

19. Schmidt TCS, Martins IA, Reigada ALD, Dias JF: Taxocenose de bagres marinhos (Siluriformes, Ariidae) da região estuarina de São Vicenta, SP, Brasil. Biot Neotrop 2008, 8:73-81.

20. Greenfield BK, Teh SJ, Ross JRM, Hunt J, Zhang GH, Davis JA, Ichikawa G, Crane D, Hung SSO, Deng DF, Teh FC, Green PG: Contaminant concentrations and histopathological effects in Sacramento splittail (Pogonichthys macrolepidotus). Arch Environ Contam Toxicol 2008, 55:270-281.

21. Triebskorn R, Telcean I, Casper H, Farkas A, Sandu C, Stan G, Col"arescu O, Dori T, Köhler HR: Monitoring pollution in river mures, Romania, part II: metal accumulation and histopathology in fish. Environ Monit Assess 2008, 141:177-188.

22. Costa PM, Diniz MS, Caeiro S, Lobo J, Martins M, Ferreira AM, Costa MH: Histological biomarkers in liver and gills of juvenile solea senegalensis exposed to contaminated estuarine sediments: a weighted indices approach. Aquat Toxicol 2009, 92:202-212.

23. Agência Nacional de Transportes Aquaviários - ANTAQ [http://www. antaq.gov.br/Portal/default.asp\#]

24. Abollino O, Aceto M, Saccchero G, Sarzanini C, Mentasti E: Comparison of electrochemical and spectroscopic procedures. Analyt Chim Acta 1995, 305:200-206.

25. Vazzoler AEM: Biologia e Reprodução de Peixes Teleósteos: Teoria e Prática. Maringá: Eduem; 1996.

\section{doi:10.1186/s12999-014-0012-5}

Cite this article as: Carvalho Neta et al:: A histopathological and biometric comparison between catfish (Pisces, Ariidae) from a harbor and a protected area, Brazil. Aquatic Biosystems 2014 10:12. 